\title{
Writing the Shakespeare Mask: The Novelist's Choices
}

\author{
Newton Frohlich
}

Independent Researcher, USA

Copyright $\mathrm{C} 2016$ by authors, all rights reserved. Authors agree that this article remains permanently open access under the terms of the Creative Commons Attribution License 4.0 International License

\begin{abstract}
The authorship of the works of Shakespeare by the glover from Stratfiord-on-Avon has been considered a myth almost from its inception. No less than Charles Dickins, Mark Twain, Henry and William James, Ralph Waldo Emerson, Herman Melville, Walt Whitman, Royal Shakespeare Company actors John Gielgud, Derek Jacobi, Jeremy Irons, and Michael York, British Prime Minister Benjamin Disraeli, five United States Supreme Court Justices, and thousands who signed a Declaration of Doubt About Will circulating the World-Wide Web have attested to their doubts. In response to the request by his publisher, author Newton Frohlich, commencing research connected with a sequel to his novel about Columbus, came across clues to the authorship of the works of Shakespeare. The man now considered by many to be the author of the works of Shakespeare is Edward de Vere, the 17th Earl of Oxford, the subject of Mr. Frohlich's new historical novel, The Shakespeare Mask. * Since the works of Shakespeare are considered some of the most sophisticated works of literature in the English language, it is important to know that de Vere was educated by outstanding Renaissance scholars and at Cambridge University, Oxford University and the Inns Of Court. (The man from Stratford had virtually no education except possibly grammar school till he was twelve.) * Since one-third of the plays of Shakespeare are set in Italy, Edward de Vere's life in Venice, Padua, Verona, Rome, Sicily, Mantua and Volcano is described including his work with the director of the Academy of Art in Mantua where commedia dell'arte was taught. (The man from Stratford never traveled outside of England and spoke no Italian or any other foreign language.) * Since no manuscript of the works of Shakespeare has ever been found in the hand of the author, the literary works of Edward de Vere are described along with the fact that in his life-time he was praised as the "most excellent writer" in Queen Elizabeth's court and, as England's premier nobleman, he was required to write anonymously and forbidden from publishing or staging any of his writings in its own name. (The man from Stratiord never left a single piece of writing in his hand except six signatures on his Will and mortgage.) * Since the works of Shakespeare are a veritable autobiography of the life of the life of Edward de Vere -- from the poisoning of his father to his wrongful accusation of his wife's infidelity -- the life of
\end{abstract}

de Vere is depicted from when he was five to the time of his tragic death, including his "favored," sexual relationship with the queen and his intimate relationship with Emilia Bassano, who is widely accepted as the "Dark Lady" of Shakespeare's Sonnets. (There is no evidence of any relationship between the Stratford man and Emilia Bassano,). In short, while the documentary evidence of de Vere's -- or the Stratford man's -- authorship of the works of Shakespeare is missing, the circumstantial evidence of de Vere's authorship is overwhelming. And as United States Supreme Court Justice John Paul Stevens puts it, "circumstantial evidence can be as persuasive as documentary evidence especially where, as here, there's so much of it.

Keywords Myth, Edward de Vere, The 17th Earl of Oxford, The Stratford Man, Anonymous Writer, Autobiographical Nature of de Vere's Writing

\section{Introduction}

When constructing an historical novel, for me the greatest challenge is to find the true facts that will form the basic narrative because often, over time, facts are obscured by myths.

For example, in the case of my previous historical novel, 1492: The World of Christopher Columbus, two myths obscured the truth. One myth concerned Columbus' family background. In Inquisition Spain, his Jewish roots had to be expunged. All evidence that he was the son of Spanish Jews who had been forced to convert to Catholicism before fleeing to Italy had to be eliminated. But in the Biblioteca Columbina in the Cathedral of Sevilla, I found evidence in Columbus' handwriting of his Jewish identity. The second myth was that Queen Isabella pawned her jewels to pay for Columbus' voyage to the new world when, in fact, I found a letter from Columbus to Luis de Santangel, a Jewishbankerin Barcelona, proving Santangel, not Queen Isabella, financed hi firstvoyage to America.

But in the case of the Earl of Oxford, no such documentary evidence has surfaced to prove the authorship of Shakespeare's plays by the Earl of Oxford or by the man 
from Stratford, and we are forced to rely on circumstantial evidence. Yet, as United States Supreme Court Justice John Paul Stevens has explained, circumstantial evidence can be just as persuasive when, as in the case of the Earl of Oxford, there is so much of it. Therefore, it seemed to me the historical novel that put flesh and blood on the bare bones of what we know about Oxford's life would go a long way toward establishing his authorship of the works of Shakespeare.

\section{Discussion}

The Stratford man myth is an attractive idea. That a poor commoner could write the most respected works of literature in the English language with little or no education, without traveling to Italy where a third of the plays took place, and without having any connection to the aristocratic world where 36 of the 37 Shakespeare plays are set is seductive. Everybody loves a miracle. So, my first novelistic decision was to emphasize the Earl of Oxford's extraordinary education. Not only was that education crucial to the sophistication of his writing, but it stood in stark relief to the Stratford man's lack thereof.

I discovered that Oxford's first tutor, Sir Thomas Smith, was not only England's leading Renaissance scholar, but Smith's close friend, the Italian Giralomo Cardano, studied the philosophical question "to be or not to be," and wrote a book on the subject entitled On Melancholy. That book was in Smith's library when Oxford studied there, and was likely an inspiration that later found profound expression in one of his greatest plays, Hamlet, Prince of Denmark. We know that Smith also taught him the joys of the aristocrat's sport of hawking as well as to speak Italian, Smith's favorite language besides Greek. So, by the end of Oxford's seven years with Smith, not only was he primed to write Hamlet, but The Taming of the Shrew.

Smith also cautioned Oxford that the uncontrolled outspokenness that blocked Smith's career -- he had been fired from Court for not holding his tongue -- could block the career of any nobleman, including Oxford. Moreover, he warned Oxford that England's monarchy and sumptuary laws dictated everything, from food eaten, to clothing worn, to words written and spoken. So, the moment Smith realized he was tutoring a young man whose mind was one in a million, undoubtedly he felt obliged to warn him always to shroud his authorship in anonymity.

But before Smith could review methods of coping with that problem, Oxford's father was murdered or, to be precise, Oxford believed his father was murdered. Suddenly, Oxford was the premier nobleman of England, yet he was twelve years old, a minor and therefore compelled to live in the London home of Sir, William Cecil, the queen's Prime Minister and Master of Wards. Now, another novelistic challenge was presented: how to characterize Cecil.

As with most people, Cecil was neither all good nor all bad. Smith taught Oxford always to wear the mask of anonymity, but Cecil, his over--bearing Guardian, gave him very different advice. Cecil was against Oxford becoming an independent thinker and was determined that Oxford be a pillar of the establishment. But in Cecil's house, Oxford was also introduced to a new tutor, Thomas Nowell, who taught him to read Saxo Grammaticus in Old English, a work containing the story of Amleth. We can readily conclude that when Oxford read it, he was struck by the parallels between his life and the life of that Danish prince. Each lost a father through murder. Each desired revenge. Thus, early on, he found more elements of Hamlet, the play he was to write the rest of his life. Oxford also met Cecil's daughter Anne, a five-year-old who one day he would be coerced to marry. That marriage would also find expression in Hamlet, All's Well That Ends Well, Othello, The Moor of Venice and other plays.

The emotional effect on Oxford of his father's murder is well known, but it seemed important to emphasize the monetary consequences, too. His father's death meant he inherited 106 parcels of real estate and was now one of the richest noblemen in England. That wealth provided him with the freedom to study and write, to publish and produce his plays and poems, and to travel and gain the erudition that underpinned his work. So, I depicted him studying at Cambridge University, but also at Oxford University where he produced his first play, a musical. I pointed to his study of law at the Inns of Court, where plays were the main source of entertainment. And I emphasized his service as a military aide to his uncle, Tom Radcliffe, the Earl of Sussex, who suppressed the Northern Rebellion thus laying the basis for Oxford's writing Henry the Fifth and other history plays.

I showed Oxford traveling to France, living in Italy, learning languages, acquiring acting companies, and writing plays about English history at a time when the subject wasn't even taught in England's schools. His wealth also provided him with the large resources to conduct the multiple love affairs he featured in so many of his plays and poems. His affairs with the queen and the Italian courtesan Virginia Padoanna, and with the queen's Lady-in-Waiting Anne Vavasour, and with the Dark Lady of his Sonnets Emilia Bassano, and his marriages to Anne Cecil and Elizabeth Trentham demonstrated that the works of Shakespeare are a veritable autobiography of the Earl of Oxford. In an earlier life, I practiced law in Washington and wrote about divorce. When it came to a love life, the Earl of Oxford wrote the book.

Another subject for novelistic treatment was Oxford's investment in the search for a northwest passage to the Orient, and also in the maintenance of an entourage of eight so he could travel in comfort to France, Venice, Verona, Padua, Mantua, Rome and Volcano whether by horse, by Italian canal boat, or by galleys propelled by slaves and the wind along the coast of the Adriatic Sea to Sicily and Cyprus. His life was so varied the challenge was how to prevent the book from becoming a laundry list of experiences.

And then, there was the central issue of his front man. Always I chose to emphasize the stark contrast between the 
life of the Stratford man, which was so limited, and Oxford's, which was so rich. Before Oxford employed him as his go-between, the man from Stratford worked for his glove maker father who was convicted of trading wool without a license, lending money at usurious interest rates, and failing to attend Protestant church services, for all of which he was fined heavily. Moreover, the son was a chip off the old man's block. He too was involved in the dark side of the law, conspiring with prostitutes to disturb the peace, failing to pay his income taxes, and hoarding grain during a drought. Why was this important to the novel?

Because only Oxford's employment of the Stratford man could account for the wherewithal of the Stratford man to amass the huge sums he required to support his family of nine, including parents, brothers, a sister and three children in Stratford, as well as to live in London. Only the large amount of income he collected from Oxford can explain his ability to purchase a coat of arms and the second largest house in Stratford as well as supply him with the sums of money he required to lend, to invest in real estate, and to acquire shares in an acting company and a theater lease. I did the numbers. Even if he received every penny from his share of the acting company profits, his expenditures required much more than the six to ten pounds a play he could have earned had he written 37 plays and two long poems.

Oxford's experiences in Italy were also crucial to proving his authorship. Based in Venice, he went first to Mantua to master the theatrical technique of commedia dell'arte. I read Cecil Roth's Renaissance and the Jews which explains how Leone de Sommi, the Director of the Gonzaga Duke's Academy of the Theater, introduced Shakespeare to the world of commedia dell'arte. Leone was living in Mantua when Oxford was in Italy. A Jewish exile from the Spanish Inquisition, Leone de Sommi had a profound influence on all Italian theaters and he wrote a fifty-volume manuscript discussing every aspect of play-making from make-up to sets, from writing scripts to training playwrights and actors to use commedia dell'arte with its broad range of stock characters. Wise yet talkative doctors, bragging but rich fathers, arrogant but courageous military heroes, clever but devious con men, loyal yet duplicitous servants all worked to create a theatrical experience that was spontaneous and comprehensive.

After Oxford returned to London, commedia dell'arte was one of his principle modi operandi, and the world of the theater was never the same. At the time of her death, Professor Noemi Megri of Padua was studying Oxford's Mantua experience. She had written about his travels in Italy and showed how Oxford's visit to Titian's atelier in Venice influenced his long poem, Venus and Adonis. Had she lived we would know much more about the crucial impact that Mantua had on Oxford's artistic development. I chose to dramatize her efforts.

In Venice, Oxford had a love affair with the courtesan, Virginia Padoanna, and I used her character to explain the influence of Italy on Oxford as she escorted him throughout Italy. Oxford's visit to the Venetian palazzo of Senator
Venier was also invaluable to Oxford. Venier's atelier was one of the great literary salons of Venice and his personal courtesan, the young Jewess, Veronica Franco, became a hero of Venice for convincing the king of France to lend his navy to Venice in its war with the Turks. No wonder Veronica Franco became a role model for all courtesans including Virginia Padoanna, Oxford's lover.

Sitting in a cafe in front of Venier's palazzo, it didn't take much imagination to picture the evening when movers and shakers that included Veronese and Tintoretto, celebrated the publication of Veronica's book of poetry that featured her night with the king of France. After researching the world of Venetian courtesans, it was a short novelist's step to exploring Oxford's first meeting with Virginia. I learned how Venetian courtesans functioned. Sophisticated, musical, literary, rich, beautiful and sexy, they were an English aristocrat's dream come true. So too must Virginia Padoanna have been for Oxford. After all, before he left London, in five years of marriage, he swore he'd only slept with his wife once.

Across the square in front of Venier's house is the church where Oxford met Orazio Cuoco, the tenor whose voice was so extraordinary Oxford invited him to London to sing for his queen. His sojourn in London with Oxford occupied only a few months and we know from his testimony before an Inquisition panel that Oxford treated him respectfully. But we also know from John Hamill's important work that loving men was as natural to Oxford as loving women, so Cuoco presented an opportunity to deal with Oxford's bi-sexuality. John Hamill pointed out that in at least one Shakespeare play a male character makes a gift of his girlfriend to his male friend. Also, we know that some of Shakespeare's Sonnets, his dedication of long poems to the Earl of Southampton, as well as the counterclaims against Oxford's allegations of treason, contain ample evidence of his homosexual love. But England encumbered homosexuality with criminality, and I found no hard evidence to prove Oxford's homosexual behavior beyond the realm of infatuation.

As I said before, Oxford's Italian experiences are crucial to the authorship issue. After I'd written most of my novel, I read Richard Roe's Shakespeare's Guide to Italy. Roe, also a lawyer who spent years studying Shakespeare's authorship, went to Italy often, and connected the plays Shakespeare set there with Oxford's travels. His book could have been a powerful catalyst to the cause of Oxford's authorship, especially since there's no evidence the Stratford man ever traveled to Italy, but at no point in his splendid work did Roe mention the name Oxford. Perhaps Roe was afraid if he connected Oxford to Shakespeare he'd never get his book published by a mainstream publisher but. Fortunately for us, his family appreciated the value of self-publishing and delivered his book to him on his death bed. Subsequently, his work was re--published by Harper as a kind of travel book. I used his treasure trove of facts about Italy to document Oxford's authorship. Likewise, I used Charlton Ogburn's research about William Lewyn, Oxford's companion from 
childhood. We know that before Oxford left for Europe with Lewyn and others, Cecil retained Lewyn as a kind of spy to report on his son--in-law's behavior. But in Italy, when Oxford, in Lewyn's opinion, went too far with Virginia Padoanna, instead of tattling to Cecil Lewyn resigned. Lewyn's resignation thus became a novelist's opportunity to explore Oxford's evolving attitude toward marriage and marital fidelity.

We know that, in Sicily, Oxford met Miguel Cervantes, soon to be the author of Don Quixote. In their meeting it was reported that Oxford became drunk, and Charlton Ogburn relates how a British military officer named Webbe described Oxford climbing onto a tavern table and challenging the world to a duel. Could it be Cervantes incorporated Oxford's wild behavior in his portrayal of Don Quixote? Could it be Oxford's meeting with another like-minded, brilliant writer inspired Oxford to get back to England and produce his plays? I chose to use their meeting as an opportunity to answer both questions in the affirmative.

Another crucial decision was how to deal with Oxford's relationship with his first wife, Anne Cecil. He resented having to marry her and refused to sleep with her but, when the queen conditioned her approval of his trip to Italy on his sleeping with Anne to create an heir, he acceded to the queen's demand. Then, while he was in Europe, his wife gave birth to a child but, in Paris, he heard about gossip in London that the child wasn't his. At first he refused to believe it, but as he was returning to England and crossing the Channel, he changed his mind and decided to use the allegations of his wife's infidelity to separate from her, embrace his fate as an anonymous author, and cease his life as a courtier. Why? The subject permeates All's Well That Ends Well and Othello, and I won't spoil the novel by giving you my answer here. Sufficed it to say I think my explanation, including his willingness later to accept paternity of the child, makessense.

Ultimately he and his wife reconciled but during the years they were separated, he had an affair with Anne Vavasour, another of the queen's Ladies-in-Waiting, which I also used to touch on his treatment of women. With Oxford, I found a most perplexing fellow, but Kay Redfield Jameson, Professor of Psychiatry at Johns Hopkins University Medical School and author of Touched with Fire: Manic Depression and the Artistic Temperament, was helpful. She has argued that Shakespeare was probably manic-depressive as so many creative artists are, so I used her book to explore this aspect of Oxford's probable character.

I had Oxford discuss the issues of his marriage with Emilia Bassano, the Dark Lady of his Sonnets and his mistress, because I agree with so many others that she was his soul mate. One need only read the Sonnets to understand their relationship. As Wordsworth put it so well, in the Sonnets "Shakespeare unlocked his heart."

Still another novelistic device was my emphasis on the importance of Oxford's relationship with his Uncle Tom Radcliffe, the Earl of Sussex. When his uncle was suppressing the Northern Rebellion, he appointed Oxford his aide and they shared a harrowing military experience. Afterward, when Oxford returned from Italy to find that Tom had become the queen's new Lord Chamberlain in charge of her entertainment, it made sense to conclude that the queen and his Uncle Tom were the ones behind the sudden performance of new Oxford plays in the palace and the launching of Oxford's career.

I also explored Oxford's relationship with Francis Walsingham, Queen Elizabeth's Secretary of State. When Walsingham asked Oxford to re-name his acting company The Queen's Men, and make them available to tour England to spread propaganda urging unity in confronting Spain, Oxford's professional career took another giant leap.

I invested space in Oxford's flirtation with Catholicism after he returned from Italy because the drama, music and pageantry of the Church undoubtedly impressed him. While his mother came from a devout Protestant family, and his father was Catholic, when he discovered that some of his Catholic friends were plotting to murder the queen, his patriotism took precedence over aesthetic attractions and he abandoned his flirtation with Catholicism.

Oxford accused his friends of treason about the time the queen discovered Oxford impregnated her Lady-in-Waiting. She banished him from Court, but fortunately the episode ended well for him. He was accepted back into the queen's good graces, received still more of her favors and these events provided fine opportunities to flesh out his personal life, including his sword fights with Anne Vavasour's uncle that resulted in permanent lameness of his left leg. Finally, I fleshed out Oxford's relationship with the queen. In my novel in their first meeting I alluded to the queen's possible maternity of Oxford but I did not want my book to be submerged in a subject that had muddled the film Anonymous. Therefore, I used their meeting tangentially, as a way to demonstrate their mutual precocity and susceptibility to passion.

Another issue was how to deal with the sexual relationship they are thought to have shared. She referred to Oxford as one of her "favorites," a term she also used to describe Robert Dudley, whose room in the palace adjoined hers, as well as Christopher Hatton, the Captain of her palace guards. As with Dudley, Oxford was mentioned as a potential mate for her in view of his brilliance and noble lineage, so I decided to make her sexual relationship with Oxford explicit, given Elizabeth's intense interest in attractive noblemen from Dudley to Hatton to the "Frog" Prince of France. It seemed doubly credible considering the queen and Oxford shared intellectual interests.

The queen's favoring of Oxford is crucial to determining authorship. Anyone writing the works of Shakespeare had to enjoy her good graces lest the author's satirical treatment of the queen or the aristocracy become fatal to him. We know his work was never censored. Instead, time and again he was protected. The queen also had to be the driving force behind his being awarded the extraordinary one thousand pound 
annual stipend by her Privy Council without his having to account for how he spent the money or disclose that he, a nobleman, was being paid for his theatrical services. Likewise, Oxford was acknowledged in print during his lifetime as the "most excellent" writer in her Court if only his writing could be "made known." In his speech at Audley's End in the queen's presence, his friend Gabriel Harvey is reported to have said words to the effect that "the Greeks had their mysterious great author Homer, just as England has its Oxford."

In an Author's Note, I pointed out that one hundred years after Oxford died, no one could attest to the Stratford man ever having been an author. But Samuel Johnson suggested England should not be frustrated by the lack of proof of the Stratford man's literary identity: after all, he said, the Greeks had their undocumented Homer; why couldn't England have its undocumented Shakespeare? When Johnson's friend, David Garrick, a London celebrity actor, arranged a Shakespeare Festival in Stratford, the myth of the Stratford man as the author of Shakespeare's plays was launched.

Add to that the bogus Stratford monument in Holy Trinity Church. Richard Whalen has documented how a hundred fifty years after the bust honoring the Stratford man's wool-trading father was installed; town fathers took advantage of Stratford's new-found notoriety as Shakespeare's "birthplace" to "beautify" the bust. They put a pen in his father's hand, turned the wool sack on his father's lap into a cushion, placed a piece of paper on the cushion and, voila, a monument to his father was turned into a shrine to the now famous "playwright son."

As for Oxford's end, official burial records report he died of the plague, but I found that strange because we know no nobleman who wished to live stayed in London during a plague; instead he fled to his country estate. Since Oxford still owned one or two, I took the liberty of exploring the emotional climate that made him stay in the city and precipitate his death. First, there was the trumped up, anti-semitic accusation against his, and the queen's, Jewish physician, Dr. Rodrigo Lopez, that resulted in Doctor Lopez's execution. Second, there was Oxford's loss of his lover Emilia Bassano who was forced by the queen to become the mistress of another nobleman. Third, there was the pressure on him to employ the Stratford man as a mask, thereby sealing Oxford's literary oblivion. And fourth, there was the death the year before he died, of the queen who was his mainstay. In his lifetime he had created plays and poems, organized an atelier in his home to train University Wits to write, reconciled with his wife, produced three daughters and two surviving sons (one of whom was illegitimate) and maintained an acting company that helped achieve England's national unity. But the queen's and Doctor Lopez's deaths, as well as his loss of Emilia's emotional comfort, had created an unbearable vacuum.
Oxford knew very well that employing the Stratford man would result in his literary oblivion so, as carefully as I could, I detailed how and when he met the Stratford man, how he employed him, and how much he paid him. I tried to explain the circumstances not only of his adopting his literary anonymity but of his use of a mask. I also showed how successful the arrangement was: not once did the Stratford man ever claim he was the author of Oxford's works. After Oxford died, not once did the Stratford man or anyone in his family claim the Stratford man was the author of the literary works of Shakespeare.

Finally, a word about what I cut. Originally I conceived of this novel as a "wrap-around," the story of the Earl of Oxford enclosed in a contemporary plot of a Ph.D. candidate seeking to write a dissertation based on Oxford's authorship against the opposition of her establishment professors. I made that decision trudging through the Gloucestershire countryside with my agent who argued historical novels are hard to get published, so why not disguise the story as a modern drama? But after I began to draft the book that way I showed some pages to my editor and she said, "Newt, don't force us to read about bickering professors. We're talking about Shakespeare. Give us the Earl of Oxford, unabridged."

\section{Conclusions}

Now, fifteen years after I began the project, I am even more convinced of Oxford's authorship as are so many others. Establishment professors may not be ready to accept change, but that's understandable. They received Ph.D's based on the wrong man and have much to lose should someone else be Shakespeare. But as the Earl of Oxford wrote to his brother-in-law Robert Cecil, England's Prime Minister, ". . . truth is subject to no prescription, for truth is truth though never so old, and time cannot make that false which once was true."

Oxford wrote those words on May 7, 1603, a year before he died, and they are as powerful today as they were then. He also wrote in his Sonnets that he expected his name to be buried with his body. But, with all due respect, I say, "Edward, there are people in an audience in Madison, Wisconsin at a Shakespeare Oxford Authorship Conference who disagree. I wrote a novel based in part on their fine research, and all of us are determined to keep working." Four hundred years after the creation of a myth about the authorship of the works of Shakespeare, it's still hanging around, but it's in the process of eroding. Though we may not yet have won the battle against the current generation of professors and critics, book by book, article by article, we shall persevere.

After all, Edward de Vere put it so well, 'time cannot make that false which once was true."” 